\title{
Intervensi Praktik Pembuatan Pupuk Kompos dengan Bahan Dasar Sampah Organik Rumah Tangga
}

\author{
Tia Fitriani, Icca Stella Amalia, Iding Budiman, Apip Apriyanto, Hany Noviyanti, Ridwan Hilman \\ STIKes Kuningan
}

Email: tfitriani639@gmail.com

\begin{abstract}
Abstrak
Pendahuluan: Faktor yang menyebabkan permasalahan sampah di Indonesia karena meningkatnya taraf hidup masyarakat yang tidak disertai dengan keselarasan pengetahuan tentang persampahan dan juga partisipasi masyarakat yang kurang untuk memelihara kebersihan dan membuang sampah pada tempatnya. Tujuan: kegiatan ini untuk mengetahui alternatif solusi dari masalah perilaku pengelolaan sampah dalam konteks penanganan dengan sasaran ibu-ibu PKK di Desa Darma Kecamatan Darma Kabupaten Kuningan. Metode: ceramah dengan menggunakan media power point. Instrumen penilaian terhadap pengetahuan responden yaitu menggunakan lembar kuesioner sebelum pelatihan dan sesudah pelatihan serta lembar evaluasi sebagai penilaian kegiatan. Hasil: Hasil evaluasi kegiatan menunjukkani bahwa sebagian besar peserta memiliki nilai post test lebih besar dibandingkan dengan nilai pre test yaitu sebanyak 17 orang. Hal ini menunjukkan bahwa dengan diadakannya penyuluhan dapat meningkatkan pengetahuan peserta. Kesimpulan: Kegiatan intervensi pembuatan kompos ini memberikan dampak positif pada pengetahuan ibu-ibu PKK dalam pengolahan sampah organik dengan metode ceramah dan demonstrasi.
\end{abstract}

Kata Kunci: Sampah Organik, Pupuk Kompos, Desa Darma

\section{PENDAHULUAN}

Food waste atau sampah makanan adalah jenis sampah yang berasal dari sisa makanan yang terbuang. Sampah makanan ini tidak hanya berasal dari sisa makanan yang telah dikonsumsi, tetapi juga berasal dari sampah makanan saat diproduksi. Pada akhirnya, masalah sampah makanan dapat membawa dampak buruk pada lingkungan dan manusia, sehingga harus segera diatasi. Sampah makanan juga dapat bersumber dari empat proses. Yang pertama adalah di level produksi dimana sampah makanan dapat disebabkan oleh cuaca buruk, serangan hama, dan permasalahan distribusi. Kedua, sampah makanan berproses dari proses pengolahan produk makanan. Ketiga, yang paling umum terjadi adalah saat penjualan dimana 
JURNAL PEMBERDAYAAN DAN PENDIDIKAN

KESEHATAN

VOL. 1 NO. 01, DESEMBER 2021

DOI:
Ciptaan disebarluaskan di bawah

Lisensi Creative Commons Atribusi-

NonKomersial-BerbagiSerupa 4.0

Internasional.

makanan yan tidak laku terjual akhirnya menjadi sampah makanan. Dan yang terakhir adalah saat proses konsumsi dimana makanan yang tidak termakan akhirnya berakhir di tempat sampah (Utami SF, 2019).

Sampah makanan menjadi salah satu penyumbang besar pembuangan sampah masyarakat. Menurut Badan Pengelolaan Lingkungan Hidup Jakarta pada tahun 2011 dari total 7.500ton sampah yang dihasilkan setiap hari, 4.050 ton diantaranya merupakan sampah sisa makanan. Jumlah tersebut jika dibandingkan maka setara dengan 667 gajah afrika dan mampu memberi makan hampir $11 \%$ populasi Indonesia atau sekitar 28 juta penduduk miskin. Penyumbang terbesar sampah makanan bersumber dari rumah tangga. Permasalahan ini bukanlah masalah yang terjadi hanya di Indonesia. Menurut Friends of Earth, masyarakat dunia menghasilkan 1,3ton sampah makanan setiap tahunnya. Besarnya angka sampah makanan yang terbuang disebabkan oleh tiga penyebab utama. Pertama, konsumsi masyarakat yang berlebihan. Konsumsi makanan yang tidak disertai dengan kesadaran lingkungan akan memperbanyak sampah makanan yang dihasilkan. Kedua, pengelolaan sampah yang buruk. Adanya sampah makanan merupakan hal yang tidak bisa dicegah, tetapi pengelolaan sampah makanan dengan efektif dapat mengurangi jumlah sampah makanan yang terbuang. Terakhir, belum adanya regulasi untuk mengatur dan mengawasi pelaku food waste (Idris, 2016).

Menurut Undang-Undang Nomor 18 Tahun 2008 tentang Pengelolaan Sampah dikatakan bahwa pengelolaan sampah adalah kegiatan yang sistematis, menyeluruh dan berkesinambungan yang meliputi pengurangan dan penanganan sampah. Pengelolaan sampah bertujuan untuk meningkatkan kesehatan masyarakat dan kualitas lingkungan serta menjadikan sampah sebagai sumberdaya. Cara pengelolaan yang dimaksud adalah dengan menerapkan prinsip 3R yaitu meliputi kegiatan pengurangan/pembatasan timbulan sampah (reduce), pemanfaatan kembali sampah (reuse), dan pendaur ulangan sampah (recycle). Kenyataan di lapangan menunjukan masih banyak masyarakat yang belum melakukan pengelolaan sampah di tingkat rumah tangga dengan baik, mulai dari memilah sampah, menyimpannya dan membuang sampah pada tempatnya (Undang-Undang Republik Indonesia Nomor 18 Tahun 2008, 2018).

\section{MASALAH}

Permasalahan sampah khususnya di Desa Darma masih menjadi suatu masalah yang berkembang, salah satunya terkait timbunan sampah organik. Berdasarkan data survei 
JURNAL PEMBERDAYAAN DAN PENDIDIKAN

KESEHATAN

VOL. 1 NO. 01, DESEMBER 2021

DOI:
Ciptaan disebarluaskan di bawah

Lisensi Creative Commons Atribusi-

NonKomersial-BerbagiSerupa 4.0

Internasional.

langsung ke TPS Desa Darma diperoleh informasi bahwa setiap harinya Desa Darma dapat menghasilkan sampah hingga 500 ton dari beberapa rumah tangga. Sampah tersebut terdiri dari sampah organik dan non organik. Permasalahan di masyarakat masih banyak yang belum memahami terkait pengelolaan sampah organik maupun non organik dengan baik dan benar. Hal ini memungkinkan dapat membuat timbunan sampah pun semakin meningkat.

\section{METODE PELAKSANAAN}

Target populasi yang dipilih dalam pelaksanaan kegiatan pengabdian masyarakat ini adalah ibu-ibu PKK yang ada di Desa Darma Kecamatan Darma Kabupaten Kuningan yang berjumlah 17 orang. Metode yang digunakan pada kegiatan ini adalah ceramah dengan menggunakan media power point. Instrumen penilaian terhadap pengetahuan responden yaitu menggunakan lembar kuesioner sebelum pelatihan dan sesudah pelatihan serta lembar evaluasi sebagai penilaian kegiatan.

Tahapan Kegiatan Pengabdian Masyarakat :

\section{Tahap 1 ( Orientasi Dengan Kepala Desa)}

Melakukan small discussion dengan kepala desa pada tanggal 16 agustus2021 ertemapat dikantor kepala Desa Darma untuk merumuskan hasil analisis yang dilakukan saat PBL 1 sekaligus meminta saran terkait permasalah pengolahan sampah organik dan meminta dukungan saat pelaksanaan pengabdian masyarakat intervensi yang akan dilaksanakan.

2. Tahap 2 ( Diskusi kelompok )

Diskusi kelompok dilakukan oleh seluruh anggota kelompok 8 Darma pada tanggal 22 agustus 2021 dimasjid kadugede untuk menentukan dan merancang sasaran dan kegiatan intervensi yang akan dilaksanakan kepada ibu-ibu PKK di Desa Darma. Setelah hasil diskusi ditentukan tupoksi masing-masing anggota dalam kegiatan pengabdian masyarakat. Disusun pula rangkaian kegiatan serta waktu kegiatan akan berlangsung.

3. Tahap 3 ( Diskusi Bersama Ketua PKK Desa Darma )

Diskusi Bersama Ketua PKK Desa Darma ini pada tanggal 27 agustus 2021 bertempat di Balai Desa Darma untuk memaparakan rancangan kegiatan pengabdian masyarakat intervensi yang akan dilaksanakan.

4. Tahap 4 (Pelaksanaan Kegiatan Intervensi)

Kegaiatan intervensi ini dilaksanakan Tanggal 8 agustus 2021 bertempat di Desa Darma yang dihadiri oleh ibu PKK yang berjumlah 17 orang. Dalam kegiatan ini dibuka oleh 
JURNAL PEMBERDAYAAN DAN PENDIDIKAN

KESEHATAN

VOL. 1 NO. 01, DESEMBER 2021

DOI:
Ciptaan disebarluaskan di bawah

Lisensi Creative Commons Atribusi-

NonKomersial-BerbagiSerupa 4.0

Internasional.

ketua PKK Desa Darma. Selanjutnya pengisian kuisoner sebelum penyuluhan terkait sampah serta kompos oleh mahasiswa. Setelah pengisian kuesioner pre test kemudian pemaparan materi oleh mahasiswa. Responden memperhatikan setiap materi yang disampaikan dengan baik, mereka mencatat hal-hal yang penting dari materi yang disampaikan. Setelah dilakukan pemaparan materi, selanjutnya dilakukan demonstrasi pembuatan pupuk kompos dengan bahan dasar sampah organik rumah tangga. Antusias para peserta pengemas dengan ikut serta ketika pembuatan ini membuat suasana pelatihan pembuatan kompos menjadi seru sehingga peserta tidak merasa bosan. Untuk menambah keseuran pelaksanaan kegiatan pengemas melalui praktik pembuatan kompos, mahasiswa memberikan games kepada peserta terkait materi yang sudah disampaikan serta aplikasi pembuatan pupuk kompos untuk kemudian dijawab peserta dan akan mendapatkan hadiah sebagai penghargaannya. Di akhir kegiatan peserta diberikan kembali isian kuesioner post test untuk mengukur tingkat oengetahuan setelah diberikan penyuluhan serta pelatihan pembuatan pupuk kompos. Serta dilakukan pengisian lembar evaluasi kegiatan untuk mengukur keberhasilan kegiatan tersebut.

\section{HASIL DAN PEMBAHASAN}

Untuk mengukur keberhasilan kegiatan pengabdian masyarakat ini dilakukan pengukuran pengetahuan melalui kuesioner pre test dan post test. Hasil yang diperoleh akan dibandingkan untuk dilihat perubahannya.

Tabel 1. Distribusi Frekuensi Pengetahuan Sebelum dan Sesudah Penyuluhan

\begin{tabular}{lcccc}
\hline \multicolumn{1}{c}{ Sebelum Penyuluhan } & \multicolumn{3}{c}{ Sesudah Penyuluhan } \\
\hline \multicolumn{1}{c}{ Pengetahuan } & Frekuensi & Persentase (\%) & Frekuensi & Persentase (\%) \\
\hline Kurang & 3 & 17,6 & 0 & 0 \\
Cukup & 11 & 64,7 & 0 & 0 \\
Baik & 3 & 17,6 & 17 & 100 \\
\hline Total & $\mathbf{1 7}$ & $\mathbf{1 0 0}$ & $\mathbf{1 7}$ & $\mathbf{1 0 0}$ \\
\hline
\end{tabular}

Berdasarkan Tabel 1. menunjukkan bahwa pengetahuan responden sebelum dilakukan intervensi memiliki nilai yang kurang sebesar $17,6 \%$, nilai cukup sebesar 64,7\% dan nilai baik hanya sebesar $17,6 \%$. Sedangkan persentase hasil setelah dilakukan intervensi menunjukan bahwa nilai pengetahuan responden mengalami peningkatakn menjadi $100 \%$. 
JURNAL PEMBERDAYAAN DAN PENDIDIKAN

KESEHATAN

VOL. 1 NO. 01, DESEMBER 2021

DOI:
Ciptaan disebarluaskan di bawah

Lisensi Creative Commons Atribusi-

NonKomersial-BerbagiSerupa 4.0

Internasional.

Menurut (Setyorini D., Saraswati R., 2006) agar pembuatan kompos berhasil maka syarat yang diperlukan antara lain:

1. Ukuran bahan mentah. Sampai batas tertentu, semakin kecil ukuran potongan bahan mentahnya, semakin cepat pula waktu pembusukannya. Ukuran bahan sekitar $5-10 \mathrm{~cm}$ sesuai untuk pengomposan ditinjau dari aspek sirkulasi udara yang mungkin terjadi.

2. Suhu dan ketinggian bahan. Makin tinggi volume timbunan makin mudah timbunan menjadi panas, sebaliknya apabila terlalu dangkal akan kehilangan panas dengan cepat.

3. Nisbah C/N. Mikroba perombak bahan organik memerlukan karbon sebagai sumber energi untuk pertumbuhan dan nitrogen untuk pembentukan protein.

4. Kelembaban. Timbunan kompos haru selalu lembab, dengan kandungan lengas 50-60\% agar mikroba tetap beraktivitas.

5. Aerasi. Aktivitas mikroba aerob memerlukan oksigen selama proses perombakan berlangsung.

6. Nilai pH. pH optimum berkisar 5,5- 8,0. Pada pH tinggi terjadi kehilangan nitrogen akibat volatilisasi. Pada awal pengomposan umumny pH agak masam karena aktivitas bakteri menghasilkan asam. Namun selanjutnya $\mathrm{pH}$ akan bergerak menuju netral.

Selama ini masyarakat belum terlalu paham dengan manfaat kompos. Padahal kompos mempunyai manfaat diantaranya adalah:

1. Memperbaiki struktur tanah berlempung sehingga menjadi ringan

2. Memperbesar daya ikat tanah berpasir sehingga tanah tidak berderai

3. Menambah daya ikat tanah terhadap air dan unsur-unsur hara tanah

4. Memperbaiki drainase dan tata udara dalam tanah

5. Mengandung unsur hara yang lengkap, walaupun jumlahnya sedikit (jumlah ini tergantung dari bahan pembuat pupuk organik)

6. Membantu proses pelapukan bahan mineral

7. Memberi ketersediaan bahan makanan bagi mikrobia serta

8. Menurunkan aktivitas mikroorganisme yang merugikan (yovita, 2001)

Bahan untuk pembuatan kompos sangat mudah diperoleh karena tersedia disekitar kita, dan cara pembuatannya pun sangat mudah semua orang bisa membuat baik dalam skala besar maupun untuk keperluan pekarangan rumah sendiri. Akan tetapi masih kurangnya pengetahuan dan keterampilan tentang pembuatan pupuk kompos berbahan sumber daya 
JURNAL PEMBERDAYAAN DAN PENDIDIKAN

KESEHATAN

VOL. 1 NO. 01, DESEMBER 2021

DOI:
Ciptaan disebarluaskan di bawah

Lisensi Creative Commons Atribusi-

NonKomersial-BerbagiSerupa 4.0

Internasional.

lokal, membuat masyarakat enggan untuk membuatnya, maka dari itu perlu adanya pelatihan pembuatan pupuk kompos.

Pada pembuatan kompos ini digunakan limbah bahan organik yang ada disekitar lingkungantempat tinggal responden, seperti hijaun/dedaunan, bonggol pisang, kotoran sapi. Metode pengomposan yang dilakukan yaitu secara aerob maupun anaerob. Menurut (Simanungkalit RDM., Suriadikarta D A., Saraswati R., Setyorini D., 2009) terdapat beberapa metode pengomposan antara lain:

1. Metode Indore.

Pengomposan dilakukan di dalam lubang, yang dibuat dekat kandang ternak. Lubang berukuran kedalaman $1 \mathrm{~m}$, lebar 1,5-2 m, panjang lubang tergantung dari ketersediaan bahan. Bahan dasar yang digunakan adalah campuran sisa/residu tanaman, kotoran ternak, urine ternak, abu bakaran kayu, dan air. Bahan yang keras tidak boleh melebihi $10 \%$. Semua bahan yang tersedia disusun menurut lapisanlapisan dengan ketebalan masing-masing $15 \mathrm{~cm}$, dengan total ketebalan 1,0-1,5 m. Setiap lapisan disiram urine ternak secara merata, kelembaban tumpukan dijaga sekitar 90\%. Pembalikan dilakukan 3 kali, yaitu pada 15, 30 dan 60 hari setelah kompos mulai dibuat. Metode ini juda disebut metode anaerob.

2. Metode heap.

Pengomposan dilakukan di permukaan tanah. Petak timbunan dibuat berukuran lebar $2 \mathrm{~m}$, panjang $2 \mathrm{~m}$ dan tinggi timbunan 1,5 m. Lapisan dasar pertama adalah bahan yang kaya karbon setebal $15 \mathrm{~cm}$ (dedaunan, jerami, serbuk gergaji, dan batang jagung), lapisan berikutnya adalah bahan yang kaya nitrogen setebal 10-15 cm (residu sisa tanaman, rumput segar, kotoran ternak, dan sampah organik). Timbunan disusun hingga ketinggian 1,5 m. Kelembaban dijaga dengan menambahkan air secukupnya. Pembalikan dilakukan setelah 6 dan 12minggu setelah proses pengomposan berlangsung.

3. Metode Berkeley.

Bahan dasar yang digunakan adalah: dua bagian bahan organik kaya selulosa dan satu bagian bahan organik kaya nitrogen dengan nilai rasio $\mathrm{C} / \mathrm{N}$ 30:1. Bahan disusun berlapis-lapis hingga ketebalan berukuran 2,4 x 2,2 x 1,5 m. Setelah 2-3 hari proses pengomposan berjalan terbentuk suhu tinggi, secara berkala kompos harus 
JURNAL PEMBERDAYAAN DAN PENDIDIKAN

KESEHATAN

VOL. 1 NO. 01, DESEMBER 2021

DOI:
Ciptaan disebarluaskan di bawah

Lisensi Creative Commons Atribusi-

NonKomersial-BerbagiSerupa 4.0

dibalik. Setelah hari ke10, suhu mulai menurun dan bahan berubah menjadi remah dan berwarna coklat gelap. Pengomposan selesai setelah 2 minggu.

Selain bahan utama sebagai bahan dasar pembuatan kompos diperlukan bahan lain seperti dekomposer/aktivator, sekam padi/serbuk gergaji, gula pasir, serta air. Kompos bisa dibuat secara alamiah namun proses ini memerlukan waktu yang lama, karena mikroorganisme pengurainya sedikit, oleh karena itu ditambahkan dekomposer untuk mempercepat proses pengomposan. Dekomposer akan mempengaruhi pembuatan kompos dengan dua cara yaitu inokulasi strain mikroorganisme yang efektif dalam menghancurkan bahan organik dan meningkatkan kadar nitrogen yang merupakan makanan tambahan bagi mikroorganisme tersebut (Gaur, 1983). Dekomposer kompos bisa dibuat sendiri dengan memanfaatkan sumber daya alam/bahan -bahan organik yang ada disekitar kita seperti bonggol pisang, daun gamal, rebung, sisa buah-buahan dan lainlaian. Bahan-bahan ini mengandung mikroorganisme sehingga disebut juga MOL (mikroorganisme lokal). Akan tetapi sekarang sudah banyak dijual di kios-kios pertanian dekomposer yang mengandung berbagai bakteri pengurai yang bisa sesuai dengan bahan dasar pembuatan kompos.

Pada pembuatan kompos ini juga ditambahkan sekam padi. Sekam padi berfungsi sangat baik untuk meningkatkan kualitas kompos dari segi teksturnya selain untuk mengurangi kelebihan air. Selain itu juga ditambahkan gula pasir yang berfungsi untuk sumber energi bagi mikroorganisme pengurai selama proses pembuatan kompos. Air juga dibutuhkan kehidupan mikroorganisme didalam dekompser kompos. Langkah selanjutnya dalam proses pembuatan kompos ini adalah bahan-bahan yang besar dipotong-potong atau dicincang dengan ukuran 2-4 cm. Pada pemotongan bahan tidak boleh terlau besar karena mengakibatkan proses penguraian berjalan lambat sedangkan kalau terlalu kecil akan menyebabkan terurainya/hilangnya difusi oksigen sehingga akan terjadi aktivitas bakteri anaerob. Bentuk bahan berpengaruh terhadap kelancaran difusi oksigen yang diperlukan serta karbondioksida yang dihasilkan (HU, 2002). Selanjutnya bahan baku disusun berlapis, lapisan dasar yang pertama adalah kotoran sapi kemudian berturut-turut potongan daun-daunan, bonggol pisang sekam padi, setelah itu siram dengan air gula dan dekomposer bergantian sedikit-sedikit sampai lembab.

Kelembaban yang dibutuhkan adalah sekitar 50-60\% agar mikroba tetap beraktivitas. Kelembaban yang lebih rendah atau lebih tinggi akan menyebabkan mikroorganisme tidak 
JURNAL PEMBERDAYAAN DAN PENDIDIKAN

KESEHATAN

VOL. 1 NO. 01, DESEMBER 2021

DOI:
Ciptaan disebarluaskan di bawah

Lisensi Creative Commons Atribusi-

NonKomersial-BerbagiSerupa 4.0

Internasional.

berkembang atau mati. Selanjutnya dibuat lapisan lagi seperti lapisan pertama dan seterusnya sampai ketinggian maksimal 1,5 m. Setelah Proses pengomposan juga sangat dipengaruhi aerasi. Aerasi yang cukup akan memperlancar proses pengomposan. Jika aerasi terlalu tinggi maka penguapan air dan kehilangan panas meningkat, sehingga memperlambat proses penguraian bahan organik. Sedangkan jika aerasi tidak cukup maka proses penguraian lambat (I, 1997).

Pupuk kompos sangat berperan dalam peningkatan produksi pertanian baik secara kualitas maupun kuantitas, mengurangi pencemaran lingkungan, dan meningkatkan kualitas lahan secara berkelanjutan. Kompos banyak mengandung mikroorganisme, dengan ditambahkannya kompos ke dalam tanah akan memacu perkembangan mikroorganisme dalam tanah, gas $\mathrm{CO} 2$ yang dihasilkan mikroorganisme akan dipergunakan untuk fotosintesis tanaman dan menghasilkan hormon-hormon pertumbuhan (MF, 2013).

Pelatihan pengelolaan sampah melalui pembuatan kompos menggunakan beberapa media diantaranya tanah, sampah organic (sayuran dan dedaunan kering), pupuk kompos yang sudah jadi, larutan EM4, larutan gula, sarung tangan dan wadah yang telah dilubangi. Sedangkan, metode yang digunakan untuk pembuatan kompos yaitu dengan memeragakan cara pembuatan kompos menggunakan sampah organic secara bertahap dan memperlihatlan kompos yang sudah jadi dari sampah organic. Adapun metode pembuatan kompos dilakukan menggunakan 3 cara yaitu:

1) Tanpa media tambahan

a. Cacah sampah organik rumah tangga hingga berukuran kecil.

b. Jika tekstur sampah organik terlalu basah keringkan terlebih dahulu

c. Larutkan cairan EM4 dengan air lalu semprotkan ke bahan kompos

d. Campurkan air gula ke dalam bahan kompos sebagai energi untuk pengurai

e. Tambahkan pupuk jadi dengan perbandingan 1:1. Aduk rata

f. Masukkan dalam wadah pengomposan

g. Tutup rapat

h. Aduk seminggu sekali agar aerasi (aliran udara) dalam wadah berlangsung baik.

2) Menggunakan Media Tambahan

a. Cacah sampah organik rumah tangga hingga berukuran kecil.

b. Tambahkan tanah secukupnya 
JURNAL PEMBERDAYAAN DAN PENDIDIKAN

KESEHATAN

VOL. 1 NO. 01, DESEMBER 2021

DOI:
Ciptaan disebarluaskan di bawah

Lisensi Creative Commons Atribusi-

NonKomersial-BerbagiSerupa 4.0

Internasional

c. Larutkan cairan EM4 dengan air lalu semprotkan ke bahan kompos

d. Campurkan air gula sebagai energi untuk proses penguraian. Aduk rata

e. Masukkan dalam wadah pengomposan

f. Tutup rapat

g. Aduk seminggu sekali agar aerasi (aliran udara) dalam wadah berlangsung baik.

3) Menggunakan Campuran Kompos Yang Sudah Jadi

a. Cacah sampah organik rumah tangga hingga berukuran kecil.

b. Tambahkan pupuk jadi dengan perbandingan 1:1. Aduk rata

c. Masukkan dalam wadah pengomposan

d. Tutup rapat

e. Aduk seminggu sekali agar aerasi (aliran udara) dalam wadah berlangsung baik.

\section{KESIMPULAN DAN SARAN}

Kegiatan intervensi pembuatan kompos ini memberikan dampak positif pada pengetahuan ibu-ibu PKK dalam pengolahan sampah organik dengan metode ceramah dan demonstrasi. Berdasarkan hasil kusioner pre test sebelum diberikan materi dan demontrasi ibu PKK tidak terlalu paham terkait pengolahan sampah organik namun setelah diberikan materi dan demontrasi yang baik dan benar hasil post test pengolahan sampah organik menunjukkan hasil yang meningkat terkait pengetahuan ibu-ibu PKK.

\section{UCAPAN TERIMA KASIH}

Kami ucapkan terimakasih kepada seluruh pihak yang telah terlibat untuk mensukseskan acara ini baik itu pemerintah desa, masyarakat maupun pihak kampus. Kami berharap semoga kegiatan ini dapat bermanfaat khususnya untuk kami dan umumnya untuk masyarakat lebih luas.

\section{DAFTAR PUSTAKA}

Gaur, A. (1983) 'A Manual of Rural Composting FAO’.

HU, S. (2002) 'Pupuk Organik Kompos dari Sampah. Bioteknologi Agroindustri.'

I, W. (1997) 'Kajian penggunaan plastik lembarandan anyaman bamboo sebagai penutup tumpukan pada pengomposan sampah kota model Cina'.

Idris, M. (2016) '13 Juta Ton Makanan Terbuang Percuma di RI Setiap Tahun', 11 Oktober 2016. Available at: https://finance.detik.com/wawancara-khusus/d-3317570/13-juta- 
JURNAL PEMBERDAYAAN DAN PENDIDIKAN

KESEHATAN

VOL. 1 No. 01, DESEMBER 2021

DOI:
Ciptaan disebarluaskan di bawah Lisensi Creative Commons Atribusi-

NonKomersial-BerbagiSerupa 4.0

Internasional.

ton-makanan-terbuang-percuma-di-ri-setiap-tahun pada 19 Agustus 2018.

MF, M. (2013) 'Pemanfaatan sampah rumah tangga untuk budidaya tanaman sayuran organik di pekarangan rumah. Agroinovasi’, pp. 17-23.

Setyorini D., Saraswati R., A. E. (2006) 'Kompos. Pupuk Organik dan Pupuk Hayati.'

Simanungkalit RDM., Suriadikarta D A., Saraswati R., Setyorini D., dan H. W. (2009) 'Teknik pembuatan kompos. Informasi Ringkas Bank Pengetahuan Padi Indonesia'.

Undang-Undang Republik Indonesia Nomor 18 Tahun 2008 (2018) Tentang Pengelolaan Sampah.

Utami SF (2019) 'Apa perbedaan food loss dan food waste'. Available at: https://zerowaste.id/zero-waste-lifestyle/perbedaan-food-loss-dan-food-waste/.

Yovita (2001) 'Membuat Kompos Secara Kilat'. 